\title{
Adenoma hepatóide supracaudal em felino (Felis catus): relato de caso
}

\section{Supracaudal hepatoide adenoma in feline (Felis catus): case report}

\author{
Lio Moreira, ${ }^{*}$ Leonardo Serafim Silveira, ${ }^{* *}$ Luciana da Silva Lemos, ${ }^{* *}$ Eulógio Carlos Queiroz de Carvalho***
}

\begin{abstract}
Resumo
Um gato macho, com 13 anos de idade, apresentou tumoração arredondada sob o tegumento íntegro, com $1 \mathrm{~cm}$ de diâmentro da face dorsal da cauda, a $3 \mathrm{~cm}$ de sua base. A histopatologia em amostras da peça, evidenciou, ao micro/HE, inúmeros adenômeros de células grandes, poliédricas, com citoplasmas eosinofílicos e núcleos redondos e centralizados, lembrando um hepatócito. Os adenômeros, algumas vezes, estavam centralizados por material eosinofílio e ligeiramente laminar, lembrando queratina. Não havendo registros de patologias nestas glândulas, se não sua hiperatividade em gatos com o comprometimento dos pêlos regionais, e conseqüente estética apenas, esta é a primeira ocorrência registrada deste tipo de neoplasia em glândula supracaudal de gato.
\end{abstract}

Palavras-chave: adenoma hepatóide, Felis catus, glândula supracaudal.

\begin{abstract}
A male cat, 13 years old, presenting a round tumor under complete tegument and measuring $1 \mathrm{~cm}$ in diameter in the dorsum and $3 \mathrm{~cm}$ distant of the base. Histopathology using micro/HE methode from surgical piece, evidenced, countless adenomerous of polyedrics and large cells with eosinophilics cytoplasms and round and central nuclei, reminding hepatocytes. In some special situation adenomerous, were centralized and souronded by eosinophilic material and showed a laminar disposition resembling keratin. No reports of pathology in such gland has been observed, otherwise hyperactivity only compromising hair apperance. Hence, this is the first case report of neoplasia involving supracaudal gland of cats.
\end{abstract}

Keywords: hepatoid adenoma, Felis catus, supracaudal gland.

\section{Introdução}

As glândulas supracaudais são um conjunto de adenômeros sebáceos bem desenvolvidos, situados numa região ovalada do dorso da cauda de cães e gatos, entre 3 e $9 \mathrm{~cm}$ de sua base, onde despeja seu produto em folículos pilosos únicos.

Foi demonstrado em gatos domésticos adultos, de ambos os sexos, a natureza sebácea modificada (hepatóide de "ordem inferior") deste anexo cutâneo. Isto, devido à sua similaridade morfofuncional, mas não topográfica, com a glândula circum-anal dos caninos. A glândula supracaudal do gato é uma típica glândula hepatóide "embrionária" previamente descrita em cães e na base de chifres de certos ruminantes. As glândulas secretam proteínas e lipídeos hidrofóbicos e têm largos ductos excretores e conectadas a folículos pilosos (Shabadash e Zelikina, 1997).

Essas glândulas nos gatos possuem todas as características das glândulas hepatóides dos caninos: células poliédricas; rede intracelular de canalículos, abundantes grânulos protéicos citoplasmáticos; liberação da secreção em folículos pilosos únicos (Monteiro-Rivieri et al., 1993). Quanto à ocorrência de patologias neste anexo cutâneo, a literatura especializada somente se refere a um embaraçamento dos pêlos da região por conta de sua secreção, quando esta está hiperativa.

Este trabalho visa relatar a transformação neoplásica benigna ocorrida nesta glândula, em gato doméstico, sem similar na literatura especializada.

\section{Material e métodos}

O material de um gato macho, SRD, com 13 anos de vida, foi fixado em formalina neutra a $10 \%$ e remetido ao Setor de Morfologia e Anatomia Patológica do Laboratório de Sanidade Animal do CCTA/UENF, para processamento por inclusão em parafina e coloração pelo $\mathrm{HxE}$.

A peça cirúrgica era uma tumoração sob epiderme íntegra (pêlos normais) com $1 \mathrm{~cm}$ de diâmetro da face dorsal da cauda, a $3 \mathrm{~cm}$ de sua base.

* Aluna de graduação em Medicina Veterinária da UENF;

** Doutorando em Anatomia Patológica Veterinária do LSA/CCTA/UENF;

***MSc. em Anatomia Patológica Veterinária e técnica de nível superior do LSA/CCTA/UENF;

${ }^{* * * *}$ PhD. em Anatomia Patológica Veterinária e professor titular MPT/UFF 


\section{Resultados e discussão}

A histopatologia em amostras da peça cirúrgica evidenciou, no HxE, inúmeros adenômeros (lóbulos) de células grandes, poliédricas, de citoplasmas eosinofílicos e núcleos redondos e centrais (lembrando o hepatócito). Os adenômeros, algumas vezes, estavam centralizados por material

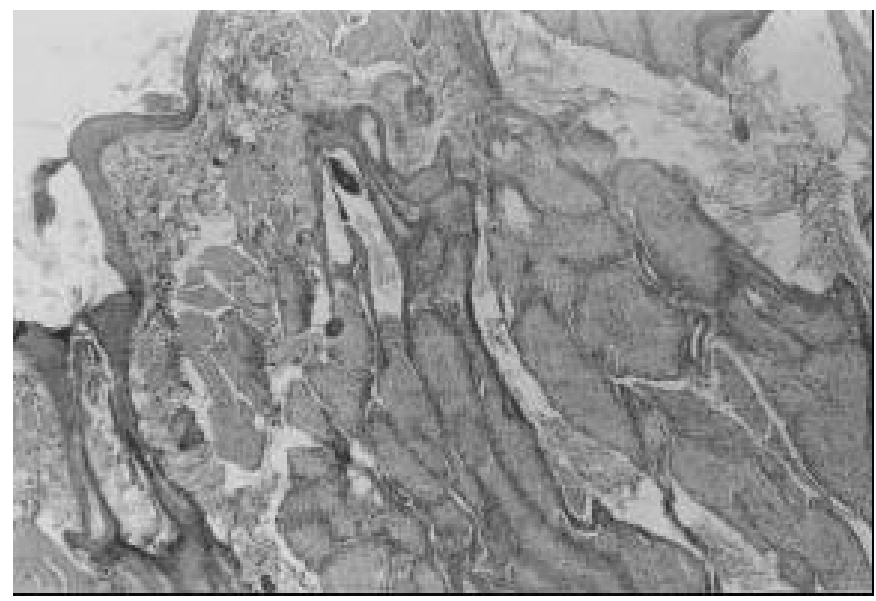

Figura 1 - Gato. Adenoma hepatóide. Glândula supracauldal. Numerosos adenômeros regulares e contidos de células sebáceas, algumas vezes centralizadas por material eosinofílico e flocular. HxE, Obj.20x. eosinofílico e ligeiramente flocular. O processo estava regularmente disposto e contido (Figuras 1 e 2).

Não havendo registros de patologias nestas glândulas, senão a sua hiperatividade em gatos com o compromisso dos pêlos regionais e, conseqüentemente, da estética apenas, esta é a primeira ocorrência de neoplasia registrada em glândula supracaudal de gato.

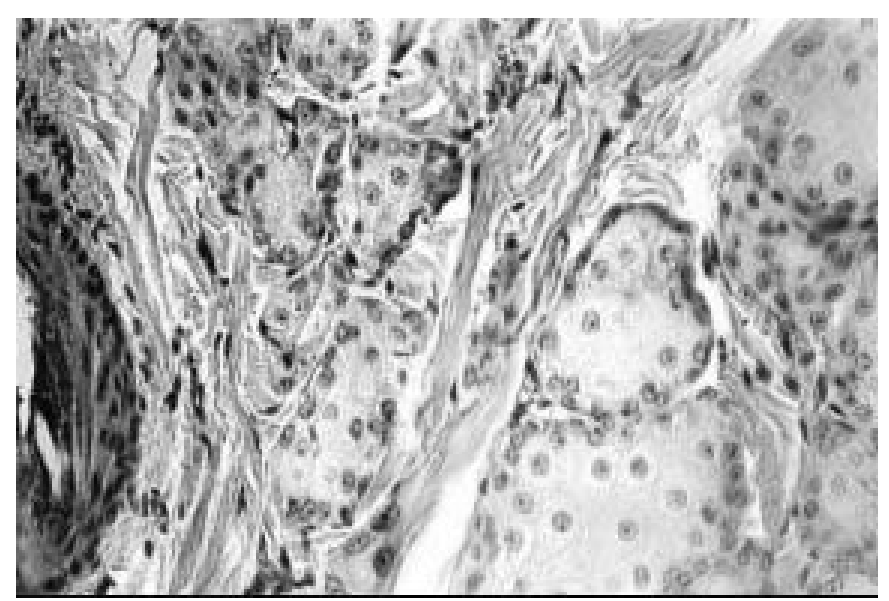

Figura 2 - Gato. Adenoma hepatóide. Glândula supracaudal. Adenômeros sebáceos, regulares de células poliédricas, núcleos redondos e centrais e células de reserva com núcleos basofílicos. HxE, Obj.40x

\section{Agradecimento}

À médica-veterinária, Dra. Érica Gomes Terra, pelo envio do material, motivo deste estudo.

\section{Referências}

MONTEIRO-RIVIERI, N. A.; STINSON. A. W.; CALHOUN, H. L. Integument. DELMANN, HD. In: Test Book of Veterinary Histology, $4^{\text {th }}$ Ed Philadelphia: Lea \& Febiger. 1993, cap.16 p. 285-312;
SHABADASH, S. A.; ZELIKINA, T. I. The Caudal Gland in the cat is a Hepatoid Gland. Izv Akad Nauk Ser Biol, 1997, Sep-Oct; v. 5, p. 556570. 